\title{
Methanotrophic activity and diversity in different Sphagnum magellanicum dominated habitats in the southernmost peat bogs of Patagonia
}

\author{
N. Kip ${ }^{1}$, C. Fritz ${ }^{2,3}$, E. S. Langelaan ${ }^{1}$, Y. Pan ${ }^{4}$, L. Bodrossy $y^{4,5}$, V. Pancotto ${ }^{6}$, M. S. M. Jetten ${ }^{1}$, A. J. P. Smolders ${ }^{2}$, and \\ H. J. M. Op den Camp ${ }^{1}$ \\ ${ }^{1}$ Radboud University Nijmegen, Institute for Water and Wetland Research (IWWR), Department of Microbiology, \\ Heyendaalseweg 135, 6525 AJ Nijmegen, The Netherlands \\ ${ }^{2}$ Radboud University Nijmegen, Institute for Water and Wetland Research (IWWR), Department of Aquatic Ecology \\ Heyendaalseweg 135, 6525 AJ Nijmegen, The Netherlands \\ ${ }^{3}$ University of Groningen, Centre for Energy and Environmental Studies, Nijenborgh 4, 9747 AG, Groningen, \\ The Netherlands \\ ${ }^{4}$ Bioresources Unit, AIT, Austrian Institute of Technology GmbH, 2444 Seibersdorf, Austria \\ ${ }^{5}$ CSIRO, Marine and Atmospheric Research and Wealth from Oceans, National Research Flagship, Hobart \\ Tasmania 7000, Australia \\ ${ }^{6}$ CADIC-CONICET, B. Houssay 200, 9410 Ushuaia, Tierra del Fuego, Argentina \\ Correspondence to: H. J. M. Op den Camp (h.opdencamp@ science.ru.nl)
}

Received: 31 August 2011 - Published in Biogeosciences Discuss.: 19 September 2011

Revised: 13 December 2011 - Accepted: 16 December 2011 - Published: 4 January 2012

\begin{abstract}
Sphagnum peatlands are important ecosystems in the methane cycle. Methanotrophs living inside the dead hyaline cells or on the Sphagnum mosses are able to act as a methane filter and thereby reduce methane emissions. We investigated in situ methane concentrations and the corresponding activity and diversity of methanotrophs in different Sphagnum dominated bog microhabitats. In contrast to the Northern Hemisphere peat ecosystems the temperate South American peat bogs are dominated by one moss species; Sphagnum magellanicum. This permitted a species-independent comparison of the different bog microhabitats. Potential methane oxidizing activity was found in all Sphagnum mosses sampled and a positive correlation was found between activity and in situ methane concentrations. Substantial methane oxidation activity $\left(23 \mu \mathrm{mol} \mathrm{CH} 4 \mathrm{gDW}^{-1} \mathrm{day}^{-1}\right)$ was found in pool mosses and could be correlated with higher in situ methane concentrations ( $>35 \mu \mathrm{mol} \mathrm{CH}_{4} \mathrm{l}^{-1}$ pore water). Little methanotrophic activity $\left(<0.5 \mu \mathrm{mol} \mathrm{CH}_{4} \mathrm{gDW}^{-1} \mathrm{day}^{-1}\right)$ was observed in living Sphagnum mosses from lawns and hummocks. Methane oxidation activity was relatively high $\left(>4 \mu \mathrm{mol} \mathrm{CH}_{4} \mathrm{gDW}^{-1} \mathrm{day}^{-1}\right)$ in Sphagnum litter at depths
\end{abstract}

around the water levels and rich in methane. The total bacterial community was studied using 16S rRNA gene sequencing and the methanotrophic communities were studied using a pmoA microarray and a complementary pmoA clone library. The methanotrophic diversity was similar in the different habitats of this study and comparable to the methanotrophic diversity found in peat mosses from the Northern Hemisphere. The pmoA microarray data indicated that both alpha- and gammaproteobacterial methanotrophs were present in all Sphagnum mosses, even in those mosses with a low initial methane oxidation activity. Prolonged incubation of Sphagnum mosses from lawn and hummock with methane revealed that the methanotrophic community present was viable and showed an increased activity within 15 days. The high abundance of methanotrophic Methylocystis species in the most active mosses suggests that these might be responsible for the bulk of methane oxidation. 


\section{Introduction}

Carbon dioxide and methane are important greenhouse gases and their concentrations are rising rapidly since industrial times (Forster et al., 2007). Methane and carbon dioxide emissions from peatlands contribute to the greenhouse effect, but for good prediction models more information is needed about the carbon cycle in these ecosystems. Microorganisms play an important role in the biogeochemical cycles of these peatlands and the knowledge about their diversity can help to improve our understanding of the carbon and nutrient turnover. Within peat ecosystems methane serves as an important carbon source for methane oxidizing bacteria; methanotrophs (Raghoebarsing et al., 2005; Kip et al., 2010; Larmola et al., 2010). Methanotrophs were found to be present on or inside the dead hyaline cells of Sphagnum mosses and act as a filter for methane, thereby recycling carbon of the system and reducing methane emissions (Raghoebarsing et al., 2005; Kip et al., 2010).

Peat bogs are a harsh environment for microbes to live in because of the low $\mathrm{pH}$ (around 4.5) and the low nutrient content. Microbial and methanotrophic communities have been studied in a few Sphagnum dominated peat bogs (Dedysh, 2009; Opelt and Berg, 2004; Kip et al., 2011a). The microbial communities can be investigated with molecular tools based on the bacterial 16S rRNA genes (Stackebrandt and Goebel, 1994), while methanotrophic communities can be characterized using functional genes like the methane monooxygenase genes, pmoA and mmoX (Murrell and Jetten, 2009). These genes encode subunits of the methane monooxygenase enzyme, which catalyses the first step in the methane oxidation pathway and can only be found in methanotrophs. A fast screening tool to study the diversity of methanotrophs is a pmoA based microarray that can be used to analyse the methanotrophic community of an ecosystem (Bodrossy et al., 2003).

Methanotrophs occur within the Proteobacteria, NC10 phylum and the Verrucomicrobia (Op den Camp et al., 2009; Conrad, 2009; Ettwig et al., 2010). The proteobacterial methanotrophs have been intensively studied and have been detected in peat ecosystems (Dedysh, 2009). Unfortunately, current molecular techniques designed for conventional methanotrophs are not able to detect the verrucomicrobial and NC10 methanotrophs yet. Gammaproteobacterial methane-oxidizing bacteria belong to the type I methanotrophs, which use the ribulose monophosphate pathway for formaldehyde fixation. The type II methanotrophs belong to the Alphaproteobacteria, which use the serine pathway for formaldehyde fixation. This group includes the Methylocystis-Methylosinus genera and the acidophilic methanotrophs of the genera Methylocella, Methylocapsa and Methyloferula (Vorobev et al., 2010; Dedysh, 2009; Conrad, 2009). Methylocella species were the first facultative methanotrophs described (Dedysh et al., 2000), but recently also other facultative Methylocystis and Methylocapsa species were isolated
(Im et al., 2010; Dunfield et al., 2010; Belova et al., 2011). These facultative methanotrophs have been shown to be able to survive a long period without methane in the presence of acetate, an important carbon source in peat ecosystems (Belova et al., 2011).

Most studies on methanotrophy in peatlands have been performed in the Northern Hemisphere (Dedysh, 2009) and peatlands in the Southern Hemisphere have so far received hardly any attention. South American peat lands are remote areas without human influence and have many ecological interesting features (Grootjans et al., 2010; Blanco and de la Balze, 2004). In the Northern Hemisphere many different Sphagnum species occur that cover the different hydrological niches, such as pools (wet), lawns (intermediate) and hummocks (dry), in South American peatlands only one moss species, Sphagnum magellanicum, frequently dominates these different habitats. The presence of only one moss species enables species-independent analyses of different peat habitats.

The present study describes methane oxidation activity in S. magellanicum sampled from various habitats in two different peat bogs in Tierra del Fuego, Argentina. Methanotrophic activity was studied along a gradient of methane availability. The methanotrophic communities of $S$. magellanicum mosses from the different micro habitats in one peat bog were investigated using a pmoA microarray and (pmoA and $16 \mathrm{~S}$ rRNA) clone libraries.

\section{Materials and methods}

\subsection{Study sites description}

We studied two different sites: a pure Sphagnum bog, called "high $\mathrm{CH}_{4}$ " bog $\left(54^{\circ} 45^{\prime} \mathrm{S}\right.$; $68^{\circ} 20^{\prime} \mathrm{W}, 200 \mathrm{~m}$ a.s.1.) and a mixed-cushion bog peatland, called "low $\mathrm{CH}_{4}$ " bog (54 $58^{\prime} \mathrm{S}$; $66^{\circ} 44^{\prime} \mathrm{W}, 40 \mathrm{~m}$ a.s.l.). Annual average daily air temperatures are $5-6^{\circ} \mathrm{C}$ with cold austral summers around $9^{\circ} \mathrm{C}$. July is usually the coldest month with mean temperature of $2^{\circ} \mathrm{C}$. At both bogs soil temperature is relatively low and stable through out the growing season decreasing from $8-12{ }^{\circ} \mathrm{C}$ at $5 \mathrm{~cm}$ below surface to $4-8{ }^{\circ} \mathrm{C}$ at $100 \mathrm{~cm}$ depth. The Sphagnum bog was dominated by Sphagnum magellanicum (Brid) with less than $1 \%$ cover of vascular plants like Empetrum ssp., Nothofagus ssp., Rostkovia ssp., Carex ssp., Marsiposppermum ssp. and Tetroncium ssp. Sphagnum magellanicum occupies all hydrological niches from pool to hummocks rising up to $1 \mathrm{~m}$ above the summer water table. Other Sphagna like Sphagnum falcatulum (S. cuspidatum coll.) and Sphagnum cuspidatum co-exist only in pools (Kleinebecker et al., 2007). In poor fens Sphagnum fimbriatum can be found next to $S$. magellanicum (Grootjans et al., 2010). In contrast, the mixed-cushion bog consists of little Sphagnum magellanicum. The Sphagnum mosses occupy margins of pools and form also small lawns (few square meters) embedded in a 
matrix of evergreen cushion plants (Roig and Collado, 2004). Dominating cushion plants were Astelia pumila (Forster f.) Gaudich and Donatia fasciculares Forster and Forster covering more than $70 \%$. Also the above mentioned vascular plants were present in the mixed-cushion bog. The soil below cushion plants is densely packed with tap roots $(1-2 \mathrm{~mm}$ diameter) and fine roots exceeding depths of $120 \mathrm{~cm}$ causing thorough methane oxidation (Grootjans et al., 2010; Fritz et al., 2011). Lawns of mixed-cushion bog hosted abundantly vascular plants compared to the Sphagnum bog. Pore water reflected acid conditions in both bogs (pH3.5-4.5). Peatlands studied remained unaffected by anthropogenic alteration such as drainage, agricultural use or elevated atmospheric nutrient deposition.

\subsection{Pore water methane concentration, $\mathrm{pH}$ measurements and methane emissions}

Pore water was sampled at depths of $5-10 \mathrm{~cm}$ from pools and lawns prior collecting moss and litter samples for incubation (more details see Fritz et al., 2011). Anaerobic peat water samples were taking using $5 \mathrm{~cm}$ ceramic cups (Eijkelkamp Agrisearch Equipment ${ }^{\circledR}$, Giesbeek, the Netherlands), connected to vacuum infusion flasks $(40 \mathrm{ml})$ after sampling $150 \mathrm{ml}$ to exclude internal stagnant sampler water. For deeper (litter) samples we measured methane concentrations at a depth of $30 \mathrm{~cm}$ below water level. Values of $\mathrm{pH}$ (NBS) were determined after collection using a handheld (Consort ${ }^{\circledR}$ C933, Turnhout, Belgium) and a standard pH electrode (SP10T, Consort ${ }^{\circledR}$, Turnhout, Belgium). Additional water samples were drawn with $60 \mathrm{ml}$-syringes.

Details on protocols to estimate methane emissions are given in Fritz et al. (2011).

Sphagnum samples were taken in December 2007, March 2008 and April 2008. Litter samples (dead plant material forming peat) were taken in April and December 2008. For all the samples the depth below the water table and below the surface at the day of sampling was measured. The depth below surface served as the reference for the depth of the sample below mean summer water table. Negative depths depict submerged samples.

\subsection{Methane oxidation and production tests}

Whole Sphagnum mosses were thoroughly washed and incubated in $120 \mathrm{ml}$ bottles with $1 \mathrm{ml}$ of methane. Methane was measured on a Hewlett-Packard model 5890 gas chromatograph equipped with a flame-ionization detector and a Porapak Q column (80/100 mesh). Methane production tests were performed in $60 \mathrm{ml}$ bottles containing only dinitrogen gas. Methane oxidation tests were performed at 10, 15 and $20^{\circ} \mathrm{C}$, in the dark.

\subsection{Statistical analysis}

Regression analyses (linear model) were performed in R software packages (R Development Core Team, 2010) followed by model justification procedures. We log-transformed potential methane oxidation rates before regression analysis. Multiple regressions were carried out starting with all environmental factors (Table 1) and subsequently simplified until the least adequate model was reached (stepwise backward deletion). We only included potential methane oxidation rates found in samples from patches with living Sphagnum $(n=6)$. Despite the low number of measurements models exhibited well-spread residuals.

\subsection{Bacterial and methanotrophic community analysis}

Sphagnum mosses were washed with sterile demineralized water after sampling and kept frozen at $-20^{\circ} \mathrm{C}$. Genomic DNA isolation, pmoA microarray and $m m o \mathrm{X}$ analysis was performed as described before (Stralis-Pavese et al., 2011; Bodrossy et al., 2003). All pmoA microarray data are available upon request.

For the clone library the PCR amplification of the pmoA gene was performed with two general pmoA gene primers: A682R and A189F (Holmes et al., 1995). All PCRs were performed in a gradient from 50 to 60 degrees and PCR products were combined. All PCR products were purified using the QIAquick PCR Purifications Kit (Qiagen). DNA sequencing was performed with the primers used in the PCR. The pmoA gene primers used were specific only for known methanotrophic Alpha- and Gammaproteobacteria, primers and were not expected to hybridize with the pmoA gene of methane-oxidizing Verrucomicrobia. Therefore we also designed a new primer set based on the pmoA 1 and pmoA2 of all three verrucomicrobial methanotrophs [10]: VpmoA216: 5'-GGAAAGAymGrATGTGGTGGCC-3' (forward) and VpmoA622: 5'-GTTTCnACCATnCGnATrTAyTCAGG-3' (reverse). Initial validation using a pure culture of Methyloacidiphilum fumarolicum SolV resulted in a product of the expected size and other proteobacterial cultures, including all isolated methanotrophs described in Kip et al. (2011b) were tested, did not result in a PCR product.

The pGEM-T Easy Vector System Kit (Promega) was used for ligation of the pmoA gene amplifications. Ligation was performed as prescribed by the manufacturer. pmoA gene ligation mix was transformed by heat shock exposure to XL1 Blue competent $E$. coli cells, constructed as described by Inoue et al. (1990). pDNA with ligated pmoA gene was isolated with the E.Z.N.A. ${ }^{\mathrm{TM}}$ Plasmid Miniprep Kit $\left(\mathrm{EZNA}^{\mathrm{TM}}{ }^{\mathrm{T}}\right.$ ). The pmoA gene sequences were sequenced with M13 forward and reverse primers (Invitrogen ${ }^{\mathrm{TM}}$ ), targeting vector sequences adjacent to the multiple cloning site. pDNA sequencing was performed by the sequencing facility of the UMC Sint Radboud, Nijmegen. Clone library sequences and their closes relatives were analyzed using MEGA version 4 
Table 1. Overview of ecological parameters obtained at the "high $\mathrm{CH}_{4}$ " bog and "low $\mathrm{CH}_{4}$ " bog. Sampling depths relative to water levels are positive when the sample was taken above the water level (living Spagnum moss) and negative when the sample was taken from below the water level (litter). Sample depths are indicated as measured at the day of sampling and relative to the mean summer water level. ND indicates no data. Water content is expressed in $\%$ of the wet weight.

\begin{tabular}{|c|c|c|c|c|c|c|c|c|c|c|c|}
\hline \multirow{2}{*}{ Peatland } & \multirow{2}{*}{ Microhabitat } & $\begin{array}{l}\text { Sample } \\
\text { depth }\end{array}$ & $\begin{array}{c}\text { Sample } \\
\text { depth } \\
\text { (mean) }\end{array}$ & $\begin{array}{c}{\left[\mathrm{CH}_{4}\right]} \\
\text { porewater }\end{array}$ & $\begin{array}{l}\text { Water } \\
\text { content }\end{array}$ & $\begin{array}{c}\text { Bulk } \\
\text { density }\end{array}$ & Emission & $\mathrm{pH}$ & $\begin{array}{c}\text { Methane } \\
\text { oxidation rate } \\
\text { at } 10^{\circ} \mathrm{C}\end{array}$ & $\begin{array}{c}\text { Methane } \\
\text { oxidation rate at } \\
20^{\circ} \mathrm{C}\end{array}$ & $\begin{array}{c}\text { Methane } \\
\text { production rate } \\
\text { at } 10^{\circ} \mathrm{C}\end{array}$ \\
\hline & & $\mathrm{cm}$ & $\mathrm{cm}$ & $\mu \mathrm{M} \mathrm{CH}_{4}$ & $\%$ & $\mathrm{~g} 1^{-1}$ & $\begin{array}{c}\mathrm{mg} \mathrm{CH}_{4} \mathrm{~m}^{-2} \\
\text { day }^{-1}\end{array}$ & & $\begin{array}{c}\mu \mathrm{mol} \mathrm{CH}_{4} \mathrm{gDW}^{-1} \\
\text { day }^{-1}\end{array}$ & $\begin{array}{c}\mu \mathrm{mol} \mathrm{CH}_{4} \mathrm{gDW}^{-1} \\
\mathrm{day}^{-1}\end{array}$ & $\begin{array}{c}\mu \mathrm{mol} \mathrm{CH}_{4} \mathrm{gDW}^{-} \\
\text {day }^{-1}\end{array}$ \\
\hline "High $\mathrm{CH}_{4}$ " bog & pool & -1 & -1 & $35.4 \pm 10.9$ & $96.8 \pm 0.2$ & $13.7 \pm 1.6$ & $7.6 \pm 3.5$ & $4-4.3$ & $23.5 \pm 20$ & $46.70 \pm 39.33$ & \\
\hline "High $\mathrm{CH}_{4}$ " bog, & pool & -1 & -1 & $9.4 \pm 8.6$ & $97.8 \pm 0.36$ & $5.0 \pm 0.3$ & ND & $4-4.3$ & $8.6 \pm 3.2$ & $18.10 \pm 7.19$ & \\
\hline "High $\mathrm{CH}_{4}$ " bog & lawn & 15 & 25 & $1.2 \pm 1.0$ & $94.0 \pm 0.4$ & $24.5 \pm 1.6$ & $1.7 \pm 1.6$ & $3.5-4.2$ & $0.22 \pm 0.25$ & $0.15 \pm 0.10$ & \\
\hline "High $\mathrm{CH}_{4}$ " bog & hummock & 50 & 70 & ND & $90.7 \pm 0.15$ & $26.5 \pm 3.3$ & ND & $3.5-4.2$ & $0.01 \pm 0.005$ & $0.04 \pm 0.03$ & \\
\hline "Low $\mathrm{CH}_{4}$ " bog & pool & -1 & 1 & $1.4 \pm 1.5$ & $97.7 \pm 0.16$ & $19.4 \pm 3.0$ & $5.1 \pm 5.9$ & $3.6-4$ & $0.47 \pm 0.53$ & $0.43 \pm 0.43$ & \\
\hline "Low $\mathrm{CH}_{4}$ " bog & lawn & 10 & 8 & $1.0 \pm 0.9$ & $94.8 \pm 0.29$ & $28.3 \pm 6.8$ & $5.6 \pm 4.7$ & $3.4-4$ & $0.25 \pm 0.38$ & $0.44 \pm 0.24$ & \\
\hline "Low $\mathrm{CH}_{4}$ " bog & hummock & 30 & 25 & ND & $91.5 \pm 0.47$ & $45.5 \pm 2.3$ & ND & $3.4-3.6$ & $0.04 \pm 0.0006$ & $0.14 \pm 0.10$ & \\
\hline "High $\mathrm{CH}_{4}$ " bog & $30 \mathrm{~cm}$ below lawn & -15 & -5 & between $1-407$ & 92.4 & 22.3 & ND & $4-4.5$ & $10.5 \pm 2.8$ & $13.1 \pm 1.9$ & $0.02 \pm 0.01$ \\
\hline "High $\mathrm{CH}_{4}$ " bog & $80 \mathrm{~cm}$ below lawn & -65 & -55 & $407.0 \pm 83.1$ & 94.6 & 24.3 & ND & $4.3-4.6$ & $5.2 \pm 1.9$ & $10.5 \pm 2.6$ & $0.54 \pm 0.20$ \\
\hline "High $\mathrm{CH}_{4}$ " bog & $80 \mathrm{~cm}$ below hummock & 0 & -10 & ND & 92.9 & 28.4 & ND & ND & $3.8 \pm 0.4$ & $7.0 \pm 0.4$ & $0.01 \pm 0.00$ \\
\hline
\end{tabular}

(Tamura et al., 2007). All sequences were aligned automatically using the alignment tool of MEGA4 (ClustalW). Phylogenetic trees were calculated using the Neighbor-joining method. The sequences of the pmoA gene clones were deposited in the Genbank database under accession numbers JF907375-JF907390.

\section{Results}

Samples were taken from Patagonian bogs that have not been affected by anthropogenic alteration such as drainage, agricultural use or elevated atmospheric nutrient deposition. They showed the typical pool, lawn and hummock micro habitats and the moss species present were mainly Sphagnum magellanicum. Ecological relevant parameters that have been determined in situ are represented in Table 1.

\subsection{Methane emission}

Methane emissions from both peatlands were generally low. Potential emission rates were found to be the highest in pools (>7.6 $\mathrm{mg} \mathrm{CH}_{4} \mathrm{~m}^{-2}$ day $^{-1}$ ) in the "high $\mathrm{CH}_{4}$ " bog coinciding with high methane pore water concentrations (Table 1). Emissions were substantially lower when surface peat water was depleted in methane. Lowest emissions were found in the lawn of the "high $\mathrm{CH}_{4}$ " bog. At this site the average water table was $5.5 \mathrm{~cm}$ deeper and vascular plant cover was extremely low (50-120 shoots $\mathrm{m}^{-2}$ ) compared to the lawn in the "low $\mathrm{CH}_{4}$ " bog (500-800 shoots $\mathrm{m}^{-2}$ ). Two measurements even revealed a net consumption of $5.1 \mu \mathrm{mol} \mathrm{CH}_{4} \mathrm{~m}^{-2}$ day $^{-1}$ and $252 \mu \mathrm{mol} \mathrm{CH}_{4} \mathrm{~m}^{-2}$ day $^{-1}$, respectively for "high $\mathrm{CH}_{4}$ " and "low $\mathrm{CH}_{4}$ " sites. In the pool of the "high $\mathrm{CH}_{4}$ " bog the surface methane concentration was approximately 30 times higher than in the lawn, but emissions were only 4.5 times higher. This difference might be explained by methanotrophic consumption, thereby significantly reducing methane emissions to the atmosphere. Therefore mosses were tested for methane oxidizing activity.

\subsection{Methane oxidizing activity tests}

Initial methane oxidizing activities of Sphagnum mosses from the two different peat ecosystems were determined (Table 1). Highest activity $\left(23.5 \mu \mathrm{mol} \mathrm{CH}_{4} \mathrm{gDW}^{-1}\right.$ day $\left.^{-1}\right)$ was found in mosses collected from methane rich pools $\left(35 \mu \mathrm{MCH}_{4}\right)$. Low methane oxidizing activity was found in Sphagnum mosses from aerated habitats like hummock and lawns that were typically depleted in methane $\left(<2 \mu \mathrm{MCH}_{4}\right)$. In the "low $\mathrm{CH}_{4}$ " bog the pool was depleted in methane and the methane oxidizing activity was low $\left(0.5 \mu \mathrm{mol} \mathrm{CH}_{4} \mathrm{gDW}^{-1} \mathrm{day}^{-1}\right)$ and comparable to the drier habitats like lawns and hummocks. The results show a clear positive correlation between the methane concentration in the pore water and the initial potential methane oxidation rates of the tested mosses (Fig. 1). Methane pore water concentration could explain $68 \%(p<0.05 ; F=11.8$; d.f. 4$)$ of the variation found in the potential methane oxidation rates along the different micro habitats of Sphagnum magellanicum. The combined variation of methane porewater concentration together with height of the mosses above the water table accounted for $94 \%$ of variation found in the potential methane oxidation rates $(p<0.01 ; F=39.0$; d.f. 3$)$. Potential methane oxidation rates at $20^{\circ} \mathrm{C}$ were twice as high as rates at $10^{\circ} \mathrm{C}$, resulting in a Q10 of around 2 .

Since submerged Sphagnum mosses showed highest methane oxidizing activity, correlating with the highest methane pore water concentration, we sampled Sphagnum litter (dead plant material forming peat) below the water level from the lawn and hummock in the "high $\mathrm{CH}_{4}$ " bog and tested them for methane oxidation and production (Table 1). These subsurface samples showed a high pore water methane concentration and both methane oxidation and methane production were found in these samples. The potential methane 


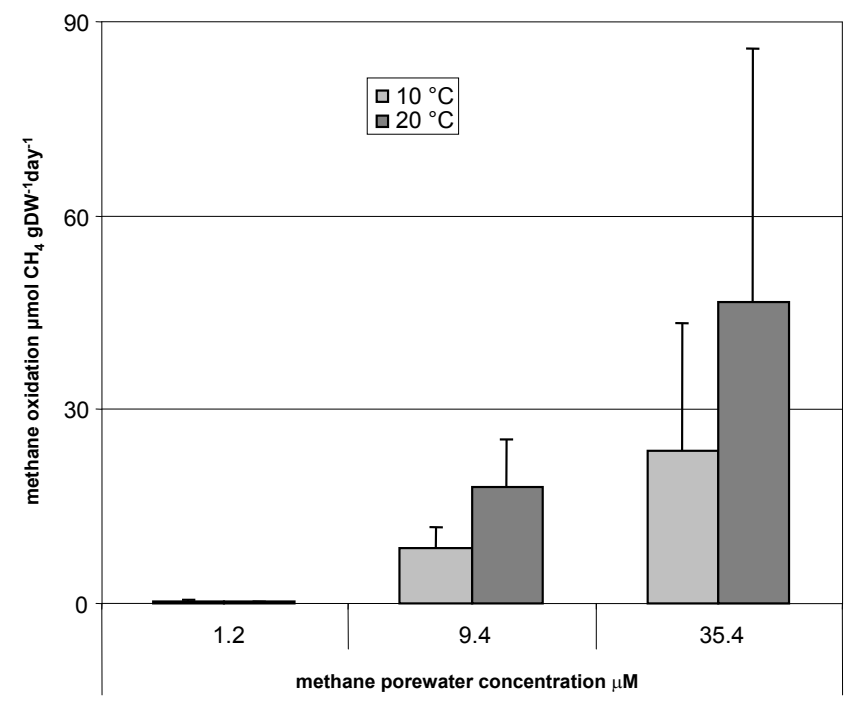

Fig. 1. Methane oxidation activities plotted against different methane pore water concentrations of the pool samples "high $\mathrm{CH}_{4}$ " bog. Activities were measured at two different temperatures: 10 and $20^{\circ} \mathrm{C}$.

oxidation rates of Sphagnum litter were substantial (3.8 to $10.5 \mu \mathrm{mol} \mathrm{CH}_{4} \mathrm{gDW}^{-1} \mathrm{day}^{-1}$ ). At even greater depths $(55 \mathrm{~cm}$ below the water table) potential methanotrophic activity was found. Measured methane oxidation rates are not representative in situ rates, due to the high oxygen concentration during incubation. Potential methane production rates were higher at $55 \mathrm{~cm}$ than at $5 \mathrm{~cm}$ in the lawn Sphagnum litter and were around $0.5 \mu \mathrm{mol} \mathrm{CH}_{4} \mathrm{gDW}^{-1} \mathrm{day}^{-1}$ at $10^{\circ} \mathrm{C}$ at $55 \mathrm{~cm}$. Submerged Sphagnum litter from the hummock showed a rather low potential methane production rate $\left(0.01 \mu \mathrm{mol} \mathrm{CH}_{4} \mathrm{gDW}^{-1} \mathrm{day}^{-1}\right.$ at $\left.10^{\circ} \mathrm{C}\right)$.

\subsection{Induced methane oxidation in lawn and hummock}

Sphagnum mosses from lawn and hummock sites showed low potential methane oxidation rates in comparison to pool mosses. Water levels and methane concentrations fluctuate in the lawns and parts can be inundated or dry in different periods of the year. In the Patagonian hummocks mosses grow up to $1 \mathrm{~m}$ above the water level and are very dry. Nevertheless, upon prolonged incubation of lawn and hummock mosses, methane oxidation increased exponentially pointing to growth of methanotrophs (data not shown). The "high $\mathrm{CH}_{4}$ " bog lawn mosses showed a threefold increase in methane oxidation potential within 2 weeks and the hummock sample needed at least three weeks of incubation with methane. The "low $\mathrm{CH}_{4}$ " lawn mosses needed almost one month to show a threefold increase in methane oxidation.

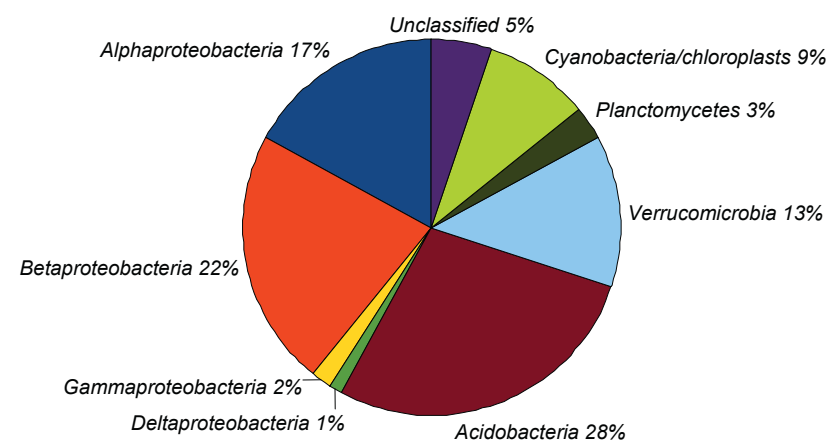

Fig. 2. Phylogenetic classification from two $16 \mathrm{~S}$ rRNA clone libraries from Patagonian Sphagnum.

\subsection{Bacterial and methanotrophic community analysis}

So far bacterial diversity studies in peatlands have been limited to sites in the Northern Hemisphere. We tried to get an insight into the diversity of bacteria and especially of methanotrophs in the Sphagnum mosses and peat litter from the different habitats in the Southern Hemisphere. Furthermore, the diversity between the same moss species growing in different micro-habitats was compared. A 16S rRNA clone library analysis was performed using mosses from the pool in the "high $\mathrm{CH}_{4}$ " bog, see Fig. 2 and the Supplementary Material for more details. The 16S rRNA gene clone libraries showed a very diverse set of bacteria to be present inside or on Sphagnum mosses. The Proteobacteria represented the biggest phylum (42\%), with a majority of Alpha- and Betaproteobacteria. Next to that the Acidobacteria (28\%) and Verrucomicrobia $(13 \%)$ were present in high numbers within the Patagonian Sphagnum mosses.

In order to investigate the presence of methanotrophs the unique functional gene marker $p m o \mathrm{~A}$, coding for a subunit of the methane monooxygenase gene was used. A pmoA clone library showed the presence of MethylocystisMethylosinus and Methylomonas species (Supplementary Material Fig. S1). For a more complete methanotrophic diversity analysis a microarray was performed. This pmoA microarray (Bodrossy et al., 2003) represents different pmoA gene sequences of cultured and non-cultured methanotrophs. pmoA PCR products from the pool and hummock samples and the litter samples of lawn $(-55 \mathrm{~cm}$ below the water level) and hummock $(-10 \mathrm{~cm}$ below the water level) from the "high $\mathrm{CH}_{4}$ " bog were hybridized onto the microarray. All samples showed a rather similar methanotrophic community, as revealed by a similar hybridization patterns on the microarray of the different samples (Fig. 3). The microarray results showed abundance of both type I (Gammaproteobacteria) and type II (Alphaproteobacteria) methanotrophs and a high methanotrophic biodiversity. The submerged Sphagnum mosses showed a higher hybridization with the type II probes over type I. The pool mosses and litter samples showed a 


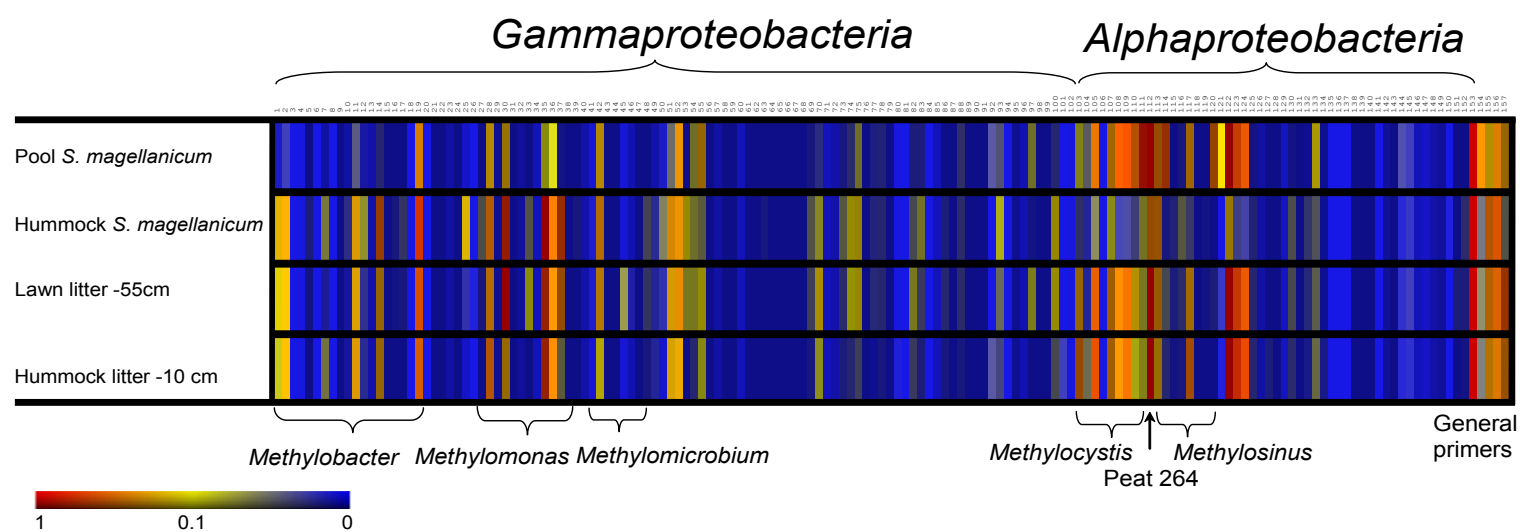

Fig. 3. Representation of the results for the pmoA based microbial methanotrophic community analysis using a pmoA microarray. All samples originate from the "high $\mathrm{CH}_{4}$ " bog. Colour coding bar on the right side represents achievable signal for an individual probe (1 indicates maximum signal obtained, 0.1 indicates $10 \%$ signal, i.e. only $10 \%$ hybridization to that probe and 0 indicates no signal). List of probes in the respective order is given in Supplementary Material Table S1.

similar hybridization pattern indicating a similar methanotrophic community at the surface and below the water table. The type II probes showed that both Methylocystis spp. and Methylosinus spp. were present in all the Sphagnum mosses, although the hummock Sphagnum mosses showed a much lower abundance and also a lower methane oxidation activity compared to all other samples. The probe Peat264, targeting a group of uncultivated peat-related alphaproteobacterial methanotrophs also showed a strong hybridization.

The microarray also showed a strong signal with the gamma-proteobacterial probes targeting the genera Methylomonas, Methylobacter and Methylomicrobium. A broad diversity of Methylomonas and Methylobacter was detected. The pmoA clone library (see above) revealed two Methylomonas-related sequences. The specific probes, which target the type $\mathrm{Ib}$ (type $\mathrm{X}$ ) methanotrophs (including the thermotolerant and thermophilic gammaproteobacterial genera Methylococcus and Methylocaldum as well as environmental clades) showed a weaker signal, but still indicated a diverse community across the analyzed samples. The viability of the methanotrophs inside hummock and lawn mosses was obvious after longer incubation times in the methane consumption experiments (see above). The microarray also confirms the presence of methanotrophs in the hummock mosses which showed very low initial methane oxidation. Unfortunately the lawn mosses did not yield enough PCR product to perform microarray analysis.

Methylocella spp., which are commonly found in Northern peatlands (Dedysh et al., 2004; Dedysh et al., 2000) and the recently discovered Methyloferula stellata (Vorobev et al., 2010) are the only known methanotrophs that do not have a pmoA gene and are therefore not detected in this microarray. These genera do have a soluble methane monooxygenase enzyme from which the encoding gene $(m m o X)$ can be also be used for phylogenetic analysis (Auman et al., 2000; Miguez et al., 1997). Searching for Methylocella spp. by screening with a mmoX-based PCR on the two pool samples did not result in any PCR product (Kip et al., 2010), indicating mmoX-possessing methanotrophs are not abundantly present or that the PCR primers are not suitable.

The PCR primers used thus far are not able to amplify verrucomicrobial pmoA genes (Pol et al., 2007). We designed new primers based on currently available verrucomicrobial sequences (see Materials and Methods) but were not able to obtain a PCR product using these primers.

\section{Discussion}

This study revealed a high activity and diversity of methanotrophic bacteria in Patagonian Sphagnum bogs. High potential rates of methane oxidation coincided with substantially reduced methane emissions especially at low water levels, reflecting an important role of the methanotrophs in reducing emissions at these sites. Methane oxidation by the living parts of the Sphagnum moss was found to be dependent on the availability of methane. This availability determines the presence and activity of methanotrophs and the water level is an important regulator as only under water logged conditions high concentrations of methane can be expected. If the mosses grow high above the water level, methane will already have been oxidized by bacteria attached to the aerobic Sphagnum litter before it reaches the living parts. However, if methane concentrations are low, like in the "low $\mathrm{CH}_{4}$ " bog, overall methanotrophic activity is low and independent of the water level. Statistical analyses also show a correlation of methane oxidation with methane pore water concentration rather than water level. Water level has been hypothesized to be the key environmental factor regulating methanotrophy in Sphagnum (Larmola et al., 2010), but our results suggest 
the methane pore water concentration to be the main driver, as was also suggested in other studies on peat ecosystems (Basiliko et al., 2007).

Living mosses collected from lawns and hummocks showed a low potential methane oxidation rate, but litter (dead parts) sampled at and below the water level showed a much higher rate. In addition, also methane production was found in these samples. The methane production and consumption activities at the same depths indicate the coexistence of contrasting micro-sites. The activity of methanotrophs and methanogens around the water level are influenced by fluctuating water levels over the year in a peat ecosystem, which makes the litter sometimes anoxic and sometimes oxic (Lai, 2009). Under both conditions microbes take their opportunities and this shows that there is not a real fixed aerobic-anaerobic interface restricting the microbial activities, like e.g. in a rice field (Lüke et al., 2010). Potential methane oxidation has also been reported in Northern peat bogs in depth samples that were anoxic under field conditions (Edwards et al., 1998).

The microbial community inside and attached to Patagonian Sphagnum mosses is comparable to previously investigated peat soils from the Northern Hemisphere (Kulichevskaya et al., 2007; Dedysh et al., 2006). Most of the 16S rRNA clones showed sequence similarity to isolates or environmental samples originating from Siberian acidic peat bogs. This points to the presence of similar bacterial communities in peatlands from both the Northern and Southern Hemisphere and implies that there is no big geographical difference.

So far, acidophilic methanotrophs belong to the Proteobacteria and Verrucomicrobia (Op den Camp et al., 2009; Conrad, 2009; Dedysh, 2009). Both groups were found in abundance in the 16S rRNA clone library, but none of the 16S rRNA sequences were closely related to currently known methanotrophs.

The pmoA clone library and microarray both showed the presence of Methylocystis and Methylomonas, which were the two families that were found to be abundant in and on Sphagnum mosses from a Dutch peat bog (Kip et al., 2011a). Recently several representatives of both families were isolated in pure culture from Sphagnum mosses and characterized (Kip et al., 2011b). The total pmoA diversity of the Sphagnum mosses was very high compared to other studies using the same microarray on peat soils (Chen et al., 2008), peat based upland soils (Cébron et al., 2007) and rice fields (Vishwakarma et al., 2009), but quite similar to the methanotrophic communities in Sphagnum mosses from other peat bogs around the world (Kip et al., 2010). Here however we have shown that all the microhabitats were showing a comparable methanotrophic community composition, considering the origin of all the different micro habitats where methane and oxygen concentrations are very different.

No $m m o X$ possessing methanotrophs were detected despite using different $m m o X$ primer combinations (Miguez et al., 1997; McDonald et al., 1995; Auman et al., 2000). This might indicate a low abundance of Methylocella species. However, several Methylomonas and Methylocystis spp. also posses the mmoX gene but remained undetected. This might be caused by a limited detection range for the primers used or because the methanotrophs present indeed do not possess a $m m o X$ gene. For future studies it could be worthwhile to test the recently described more specific Methylocella spp. real time quantitative mmoX PCR primers (Rahman et al., 2011).

There was no detection of Verrucomicrobial methanotrophs using newly designed primers. This could indicate the absence of these type of methanotrophs or they maintained undetected because of the limited sequence database, which narrows the detection range of the primers.

Despite the low potential methane oxidation rates of the dry hummock, the microarray analysis showed that methanotrophs were present. They were most probably present in very low densities, but viable, since they respond to increased availability of methane by building up an active population. Methanotrophs present in the lawn mosses reacted faster upon prolonged incubation compared to those from hummocks, which is most probably due to the in situ fluctuations in methane availability which are bigger in lawns located closed to the mean water level, than in hummocks.

The type II probes of the microarray showed that both Methylocystis sp. and Methylosinus sp. were present in all the Sphagnum mosses, although the mosses from the hummock showed a much lower abundance, which coincides with a lower methane oxidation activity compared to all other samples. The high abundance of Methylocystis spp. in the most active mosses indicates they are probably the key players in this ecosystem. The capacity to use acetate as an additional carbon source, to fix nitrogen and to consume methane at both high and low concentrations by several Methylocystis spp. might represent an important part of the survival strategy of this kind of methanotrophs in peat lands (Belova et al., 2011; Buckley et al., 2008; Im et al., 2010). This might explain why they are found in abundance in this Sphagnum dominated peatland and other ecosystems. However to test if the species present in this system are indeed capable of the above mentioned traits it is necessary to isolate and test the important methanotrophic players of the system.

\section{Supplementary material related to this article is available online at: http://www.biogeosciences.net/9/47/2012/ bg-9-47-2012-supplement.pdf.}

Acknowledgements. Nardy Kip is supported by a grant from the Darwin Centre for Biogeosciences (142.16.1061) and Mike Jetten by an ERC grant (no. 232937).

Edited by: J. Middelburg 


\section{References}

Auman, A. J., Stolyar, S., Costello, A. M., and Lidstrom, M. E.: Molecular characterization of methanotrophic isolates from freshwater lake sediment, Appl. Environ. Microb., 66, 52595266, 2000.

Basiliko, N., Blodau, C., Roehm, C., Bengtson, P., and Moore, T. R.: Regulation of decomposition and methane dynamics across natural, commercially mined, and restored northern peatlands, Ecosystems, 10, 1148-1165, 2007.

Belova, S. E., Baani, M., Suzina, N. E., Bodelier, P. L. E., Liesack, W., and Dedysh, S. N.: Acetate utilization as a survival strategy of peat-inhabiting Methylocystis spp., Environ. Microbiol. Rep., 3, 36-46, 2011.

Blanco, D. E. and de la Balze, V.: Turbales de la Patagonia, bases para su inventario y la conservación de su biodiversidad, Wetland International, Buenos Aires, 2004 (in Spanish).

Bodrossy, L., Stralis-Pavese, N., Murrell, J. C., Radajewski, S., Weilharter, A., and Sessitsch, A.: Development and validation of a diagnostic microbial microarray for methanotrophs, Environ. Microbiol., 5, 566-582, 2003.

Buckley, D. H., Huangyutitham, V., Hsu, S.-F., and Nelson, T. A.: ${ }^{15} \mathrm{~N}_{2}$-DNA-stable isotope probing of diazotrophic methanotrophs in soil, Soil Biol. Biochem., 40, 1272-1283, 2008.

Cébron, A., Bodrossy, L., Chen, Y., Singer, A. C., Thompson, I. P., Prosser, J. I., and Murrell, J. C.: Identity of active methanotrophs in landfill cover soil as revealed by DNA-stable isotope probing, FEMS Microbiol. Ecol., 62, 12-23, 2007.

Chen, Y., Dumont, M. G., McNamara, N. P., Chamberlain, P. M., Bodrossy, L., Stralis-Pavese, N., and Murrell, J. C.: Diversity of the active methanotrophic community in acidic peatlands as assessed by mRNA and SIP-PLFA analyses, Environ. Microbiol., 10, 446-459, 2008.

Conrad, R.: The global methane cycle: recent advances in understanding the microbial processes involved, Environ. Microbiol. Rep., 1, 285-292, 2009.

Dedysh, S. N.: Exploring methanotroph diversity in acidic northern wetlands: molecular and cultivation-based studies, Microbiology, 78, 655-669, 2009.

Dedysh, S. N., Liesack, W., Khmelenina, V. N., Suzina, N. E., Trotsenko, Y. A., Semrau, J. D., Bares, A. M., Panikov, N. S., and Tiedje, J. M.: Methylocella palustris gen. nov., sp nov., a new methane-oxidizing acidophilic bacterium from peat bogs, representing a novel subtype of serine-pathway methanotrophs, Int. J. Syst. Evol. Micr., 50, 955-969, 2000.

Dedysh, S. N., Berestovskaya, Y. Y., Vasylieva, L. V., Belova, S. E., Khmelenina, V. N., Suzina, N. E., Trotsenko, Y. A., Liesack, W., and Zavarzin, G. A.: Methylocella tundrae sp nov., a novel methanotrophic bacterium from acidic tundra peatlands, Int. J. Syst. Evol. Micr., 54, 151-156, 2004.

Dedysh, S. N., Pankratov, T. A., Belova, S. E., Kulichevskaya, I. S., and Liesack, W.: Phylogenetic analysis and in situ identification of Bacteria community composition in an acidic Sphagnum peat bog, Appl. Environ. Microb., 72, 2110-2117, 2006.

Dunfield, P. F., Belova, S. E., Vorobév, A. V., Cornish, S. L., and Dedysh, S. N.: Methylocapsa aurea sp. nov., a facultatively methanotrophic bacterium possessing a particulate methane monooxygenase, Int. J. Syst. Evol. Micr., 60, 26592664, 2010.

Edwards, C., Hales, B. A., Hall, G. H., McDonald, I. R., Murrell, J.
C., Pickup, R., Ritchie, D. A., Saunders, J. R., Simon, B. M., and Upton, M.: Microbiological processes in the terrestrial carbon cycle: Methane cycling in peat, Atmos. Environ., 32, 3247-3255, 1998.

Ettwig, K. F., Butler, M. K., Le Paslier, D., Pelletier, E., Mangenot, S., Kuypers, M. M. M., Schreiber, F., Dutilh, B. E., Zedelius, J., de Beer, D., Gloerich, J., Wessels, H. J. C. T., van Alen, T., Luesken, F., Wu, M. L., van de Pas-Schoonen, K. T., Op den Camp, H. J. M., Janssen-Megens, E. M., Francoijs, K.-J., Stunnenberg, H., Weissenbach, J., Jetten, M. S. M., and Strous, M.: Nitrite-driven anaerobic methane oxidation by oxygenic bacteria, Nature, 464, 543-548, 2010.

Forster, P., Ramaswamy, V., Artaxo, P., Berntsen, T., Betts, R., Fahey, D. W., Haywood, J., Lean, J., Lowe, D. C., Myhre, G., Nganga, J., Prinn, R., Raga, G., Schulz, M., and Van Dorland, R.: Changes in atmospheric constituents and in radiative forcing, climate change 2007: The physical science basis, contribution of working group I to the fourth assessment report of the intergovernmental panel on climate change, edited by: Solomon, S., Qin, D., Manning, M., Chen, Z., Marquis, M., Averyt, K. B., Tignor, M., and Miller, H. L., Cambridge University Press, Cambridge, United Kingdom and New York, NY, USA, 2007.

Fritz, C., Pancotto, V. A., Elzenga, J. T. M., Visser, E. J. W., Grootjans, A. P., Pol, A., Iturraspe, R., Roelofs, J. G. M., and Smolders, A. J. P.: Zero methane emission bogs: extreme rhizosphere oxygenation by cushion plants in Patagonia, New Phytol., 190, 398-408, 2011.

Grootjans, A., Iturraspe, R., Lanting, A., Fritz, C., and Joosten, H.: Ecohydrological features of some contrasting mires in Tierra del Fuego, Argentina, Mires and Peat, 6, 1-15, 2010.

Holmes, A. J., Costello, A., Lidstrom, M. E., and Murrell, J. C.: Evidence that particulate methane monooxygenase and ammonia monooxygenase may be evolutionarily related, FEMS Microbiol. Lett., 132, 203-208, 1995.

Im, J., Lee, S. W., Yoon, S., DiSpirito, A. A., and Semrau, J. D.: Characterization of a novel facultative Methylocystis species capable of growth on methane, acetate and ethanol, Environ. Microbiol. Rep., 3, 174-181, 2010.

Inoue, H., Nojima, H., and Okayama, H.: High efficiency transformation of Escherichia coli with plasmids, Gene, 96, 23-28, 1990.

Kip, N., van Winden, J. F., Pan, Y., Bodrossy, L., Reichart, G., Smolders, A. J. P., Jetten, M. S. M., Sinninghe Damsté, J. S., and Op den Camp, H. J. M.: Global prevalence of symbiotic bacterial methane oxidation in peat moss ecosystems, Nat. Geosci., 3, 617-6212010.

Kip, N., Dutilh, B. E., Pan, Y., Bodrossy, L., Neveling, K., Kwint, M. P., Jetten, M. S. M., and Op den Camp, H. J. M.: Ultradeep pyrosequencing of pmoA amplicons confirms the prevalence of Methylomonas and Methylocystis in Sphagnum mosses from a Dutch peat bog, Environ. Microbiol. Rep., 3, 667-673, doi:10.1111/j.1758-2229.2011.00260.x, 2011a.

Kip, N., Ouyang, W., van Winden, J. F., Raghoebarsing, A., van Niftrik, L., Pol, A., Pan, Y., Bodrossy, L., Van Donselaar, E. G., Reichart, G., Jetten, M. S. M., Sinninghe Damsté, J. S., and Op den Camp, H. J. M.: Detection, isolation, and characterization of acidophilic methanotrophs from Sphagnum mosses, Appl. Environ. Microb., 77, 5643-5654, 2011 b.

Kleinebecker, T., Holzel, N., and Vogel, A.: Gradients of continen- 
tality and moisture in South Patagonian ombrotrophic peatland vegetation, Folia Geobot., 42, 363-382, 2007.

Kulichevskaya, I., Belova, S., Kevbrin, V., Dedysh, S., and Zavarzin, G.: Analysis of the bacterial community developing in the course of Sphagnum moss decomposition, Microbiology, 76, 621-629, 2007.

Lai, D. Y. F.: Methane Dynamics in Northern Peatlands: A Review, Pedosphere, 19, 409-421, 2009.

Larmola, T., Tuittila, E.-S., Tiirola, M., Nykänen, H., Martikainen, P. J., Yrjälä, K., Tuomivirta, T., and Fritze, H.: The role of Sphagnum mosses in the methane cycling of a boreal mire, Ecology, 91, 2356-2365, 2010.

Lüke, C., Krause, S., Cavigiolo, S., Greppi, D., Lupotto, E., and Frenzel, P.: Biogeography of wetland rice methanotrophs, Environ. Microbiol., 12, 862-872, doi:10.1111/j.14622920.2009.02131.x, 2010.

McDonald, I. R., Kenna, E. M., and Murrell, J. C.: Detection of methanotrophic bacteria in environmental samples with the PCR, Appl. Environ. Microb., 61, 116-121, 1995.

Miguez, C. B., Bourque, D., Sealy, J. A., Greer, C. W., and Groleau, D.: Detection and isolation of methanotrophic bacteria possessing soluble methane monooxygenase (sMMO) genes using the polymerase chain reaction (PCR), Microb. Ecol., 33, 21-31, 1997.

Murrell, J. C. and Jetten, M. S. M.: The microbial methane cycle, Environ. Microbiol. Rep., 1, 279-284, 2009.

Op den Camp, H. J. M., Islam, T., Stott, M. B., Harhangi, H. R., Hynes, A., Schouten, S., Jetten, M. S. M., Birkeland, N.-K., Pol, A., and Dunfield, P. F.: Environmental, genomic and taxonomic perspectives on methanotrophic Verrucomicrobia, Environ. Microbiol. Rep., 1, 293-306, 2009.

Opelt, K. and Berg, G.: Diversity and antagonistic potential of bacteria associated with bryophytes from nutrient-poor habitats of the Baltic Sea coast, Appl. Environ. Microb., 70, 6569-6579, 2004.

Pol, A., Heijmans, K., Harhangi, H. R., Tedesco, D., Jetten, M. S. M., and Op den Camp, H. J. M.: Methanotrophy below pH1 by a new Verrucomicrobia species, Nature, 450, 874-878 2007.
Raghoebarsing, A. A., Smolders, A. J., Schmid, M. C., Rijpstra, W. I., Wolters-Arts, M., Derksen, J., Jetten, M. S., Schouten, S., Sinninghe Damsté, J. S., Lamers, L. P., Roelofs, J. G., Op den Camp, H. J. M., and Strous, M.: Methanotrophic symbionts provide carbon for photosynthesis in peat bogs, Nature, 436, 1153 1156, 2005.

Rahman, Md. T., Crombie, A., Chen, Y., Stralis-Pavese, N., Bodrossy, L., Meir, P., McNamara, N. P., and Murrell, J. C.: Environmental distribution and abundance of the facultative methanotroph Methylocella, ISME J., 5, 1061-1066, 2011.

Roig, C. E. and Collado, L.: Ventana $\mathrm{N}^{\circ} 7$ - Moat, in: Los Turbales de la Patagonia, bases para su inventario y la conservación de su biodiversidad, edited by: Blanco, D. E. and de la Balze, V. M., Wetlands International, Buenos Aires, 66-71, 2004 (in Spanish).

Stackebrandt, E. and Goebel, B. M.: Taxonomic note: A place for DNA-DNA reassociation and 16S rRNA sequence analysis in the present species definition in bacteriology, Int. J. Syst. Evol. Micr., 44, 846-849, 1994.

Stralis-Pavese, N., Abell, G. C. J., Sessitsch, A., and Bodrossy, L.: Analysis of methanotroph community composition using a pmoA-based microbial diagnostic microarray, Nature Protoc., 6, 609-624, 2011.

Tamura, K., Dudley, J., Nei, M., and Kumar, S.: MEGA4: Molecular Evolutionary Genetics Analysis (MEGA) software version 4.0, Mol. Biol. Evol., 24, 1596-1599, 2007.

Vishwakarma, P., Dumont, M. G., Bodrossy, L., Stralis-Pavese, N., Murrell, J. C., and Dubey, S. K.: Ecological and molecular analyses of the rhizospheric methanotroph community in tropical rice soil: effect of crop phenology and land-use history, Curr. Sci., 96, 1082-1089, 2009.

Vorobev, A. V., Baani, M., Doronina, N. V., Brady, A. L., Liesack, W., Dunfield, P. F., and Dedysh, S. N.: Methyloferula stellata gen. nov., sp. nov., an acidophilic, obligately methanotrophic bacterium possessing only a soluble methane monooxygenase, Int. J. Syst. Evol. Micr., 61, 2456-2463, doi:10.1099/ijs.0.028118-0, 2010. 